\title{
3D IPEA Model to Improving the Service Quality of Boarding School
}

\author{
Asep Saifuddin Chalim ${ }^{1,2}$ \\ ${ }^{1}$ State Islamic University of Sunan Ampel (UINSA), Surabaya, Indonesia \\ ${ }^{2}$ Islamic Religious Institutes of Al-khoziny, Buduran, Sidoarjo, Indonesia \\ Correspondence: Asep Saifuddin Chalim. Address: Islamic Religious Institutes of Al-khoziny, Buduran, Sidoarjo, \\ 61252, Indonesia. Tel: 62-821-3130-5081. E-mail: asep.chalim@gmail.com
}

Received: February 8, 2016 Accepted: March 8, 2016 Online Published: June 21, 2016

doi:10.5539/ass.v12n7p119 URL: http://dx.doi.org/10.5539/ass.v12n7p119

\begin{abstract}
The service quality is an important factor which affecting student performance, expectation and satisfaction in a boarding school. The traditional of Importance-performance analysis used to evaluate strength and weaknesses of a service quality factors. The models of Importance-Performance-GAP Analysis (IPGA) have developed by integrating the strengths of the importance and performance analysis (IPA) and the GAP analysis (Lin, et al. 2009). This study develops a 3D (three dimensions) service quality and gap model by extending the IPGA model through adding student expectations attribute. This method shows the useful of the IPEA (Importance-performance-expectation analysis) in 3D grid view and this method useful in evaluating service quality of school. This study identified 40 items and each item was rated using Likert scales that have a 5-point of levels. The results were obtained from 175 students from grade 7 to grade 12. The final result was divided in two different aspect; (1) management aspect and (2) building services and facility aspect. The IPA grid for management aspect shows that four items fall into fist quadrant (Keep up the good work), and seven items fall into the second quadrant (Concentrate here), two items fall into third quadrant (Low priority), and two items fall into forth quadrant (Possible overkill). The results of 3D IPEA are shown that two attribute putted in quadrant 3 and one attribute in quadrant 6 . The findings of the study show that a management aspect and building facilities aspect are necessary to enhance the service quality of school. The results are useful to identifying real condition of building facility and help a boarding school to develop better service quality.
\end{abstract}

Keywords: IPEA model, 3D model analysis, service quality, boarding school

\section{Introduction}

The variables of service quality increase customer satisfaction based on many researchers studies. The other side, method of importance-performance analysis is used to measure the level of customer satisfaction. The objective of this research was to evaluate the use of 3D IPEA model as a tool to measure the service quality of boarding school and evaluate the GAP between each attributes. This method can be easily implemented in other boarding schools which have similarity in attributes and as a performance outcome measure from student as respondent.

In their research, Wu et al. (2010) explain that IPA is an effective and simple method that can be applied to investigate the satisfaction of customer as a function of performance and importance attributes. Importance-performance analysis provides management rules which focuses for developing strategies (Martilla et al., 1977). The GAP Analysis and IPA are the main analytical approaches to improve the service quality according to many studies. This research develops 3D (three dimensions) of service quality gap model by extending the IPGA model through adding student expectations attribute. This method shows the usefulness of the IPEA method in 3D grid view and this method useful in evaluating service quality of school.

The results of this research are a survey based random sample of 175 students. Amanatul Ummah is an Islamic boarding school with good performance and almost all of graduated became a graduate student in famous University. The authors choose some variables that are considered important in achieving the goal.

\section{Literature Review}

The IPA proposed by Matrilla and James in 1977, it was a useful tool to provide management perspective to identify strengths and weaknesses of the object for improving the performance. Importance-performance analysis has been used as a tool to evaluate strategies and service quality in educational organizations ( $\mathrm{O}$ 'Neill et al., 
2004), in service quality of a school, and in many projects of government (Wong et al., 2011).

Since Matrilla and James reseach in 1977, the IPA framework has popular among researchers in service quality research (Ennew et al., 1993), and simple tool in evaluating service quality of higher education (Silva et al., 2011). IPA examines not only the performance of attribute, but also the importance of that item as a determining in satisfaction factor to the respondent (Silva \& Fernandes, 2010). The IPA method has proven to be a generally applicable tool which is simply to interpret result in wide uses among researchers in various fields and subject. IPA is a way to promote the development of effective strategy, because this method facilitates the interpretation of attribute and increases the usefulness in making strategic and decisions (Matzler et al., 2003; Kitcharoen, 2004; Abalo et al., 2007).

Importance of the service attributes in IPA method is plotted as the vertical (y) axis and performance levels plotted as the horizontal (x) axis. The means of performance and importance divide the grid into four quadrants; Q1 (Keep up the Good Work), Q2 (Concentrate Here), Q3 (Low Priority), and Q4 (Possible Overkill). Lin, et al., (2009) argued although the IPA method has been considered as effective technique, many researchers propose several modified approach and conceptions, based upon two implicit assumptions about the traditional IPA method. In this study, sub-attributes collected in two Cartesian diagrams; (1) management aspect and (2) service quality of the building. The different of this study from the studies which conducted by other researchers (Silva \& Fernandes, 2010; Kitcharoen, 2004; Chen et al., 2013), other researchers tends to be more simple and only use the main attributes to analyze the placement of quadrant.

In this study, IPEA model are displayed on 3D (three-dimensional) grid after expectation attribute added. The performance attributes is plotted as $\mathrm{x}$ axis, the importance attributes is plotted as $\mathrm{y}$ axis, while the expectation attributes is plotted as $\mathrm{z}$ axis. In additional, attribute of expectation is very similar with attribute of importance. Therefore, the intersection coordinates of performance-importance-expectation analysis (IPEA) shows in figure 1 below.

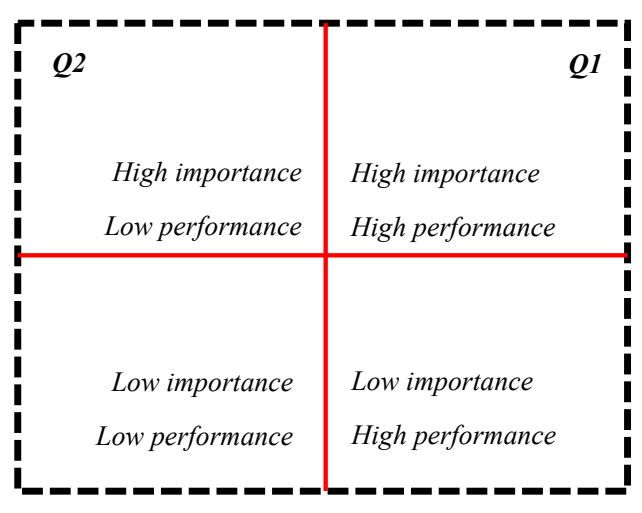

Q3
Q4

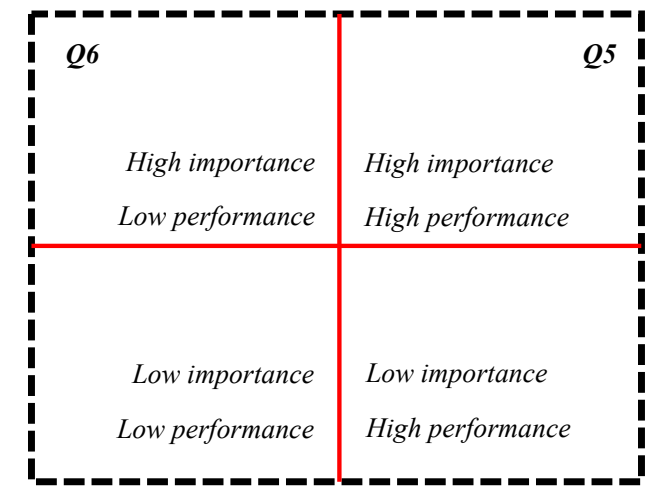

$Q^{7}$
Q8

Figure 1. Importance-performance-expectation matrix

This study tries to analyze further the cause of the gap between the service needs to be improved. Service on a three-dimensional model of the quality gap consists of three important steps including; (1) assess the respondent's perception of the importance of service attributes, levels of performance and perception of expectations on service attributes. (2) Calculated relative importance, relative performance and degree of relative importance when compared with the expected value. (3) Finding an attribute in eight quadrant of the 3D (three-dimensional) in the gaps of service quality.

Different IPGA model which introduced by Lin et al. (2009) has been developed in this study which called 3D IPEA model. The definitions of the performance of respondent expectations, the definitions of the importance of respondent expectations and the performance aspect based on respondent perceptions which compared with the value of expectation attribute. All value was found as following step;

(1) The performance for respondent expectations $(\mathrm{CPE}=\mathrm{CP}-\mathrm{CE})$; the deviation value of performance from the respondent with the value of expectation attributes. 
(2) The importance for respondent expectations $(\mathrm{CIE}=\mathrm{CI}-\mathrm{CE})$; the deviation value of importance from the respondent with the value of expectation attributes.

(3) The performance compared with the value of importance $(\mathrm{CPI}=\mathrm{CP}-\mathrm{CI})$; the deviation value of performance from the respondent with the value of importance attributes.

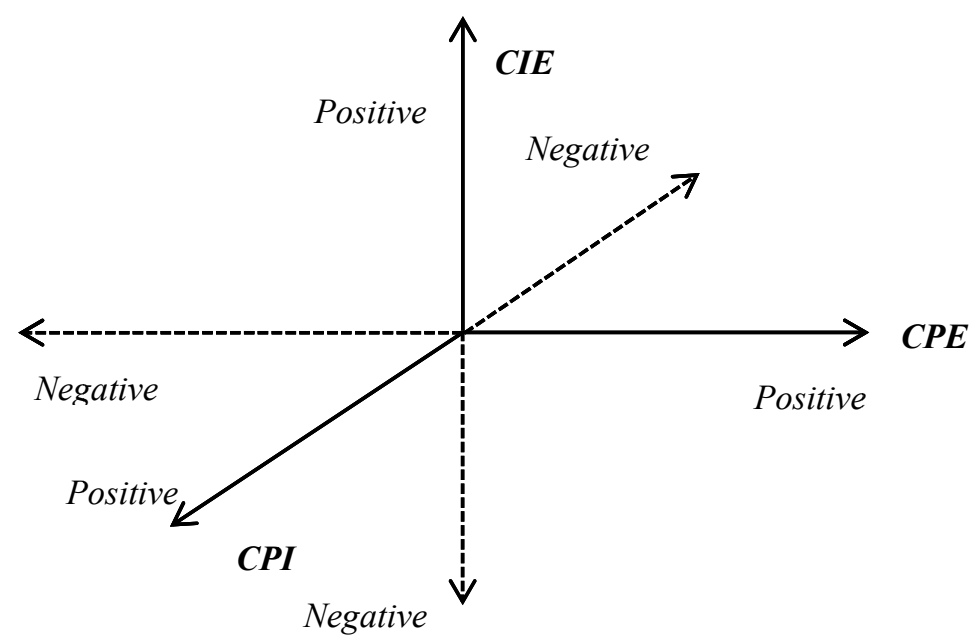

Figure 2. The 3D of service quality in IPEA model

In this study, the best value is based on the calculation of the expectation attribute, so that all attributes compared with the value of expectation attribute and balancing value obtained from the comparison between the expectation attribute and importance value. Refer to the approach above; the following table is an attribute grouping and placement quadrant of 3D IPEA model.

Table 1. The quadrant of IPEA model

\begin{tabular}{cccc}
\hline & CPE & CIE & CPI \\
\hline I & + & + & + \\
II & + & + & - \\
III & + & - & + \\
IV & + & - & - \\
V & - & + & + \\
VI & - & + & - \\
VII & - & - & + \\
VIII & - & - & - \\
\hline
\end{tabular}

\section{Methodology}

\subsection{Research Instrument}

This study measures the variables of services quality in Amanatul Ummah boarding school by surveying student perception. Research-developed instruments were used to collect information based on student perceptions in these studies. The questionnaire, covering most of the boarding school aspects, was developed based on literature and early interview with head principal and responsible people for building management.

The instrument comprised two sections; the first section consisted of four items that measured student activities and school management such as learning activity in the classroom, school facilities, school management, food 
service and teacher performance. The second section consisted of five questions that measured building and service quality in boarding school such as classroom, mosque, hostel, toilet, and cafeteria.

Likert scale measured the performance and importance attributed to each item in the first section. The "importance" of each attribute was rated using Likert scale from 5 (very important) to 1 (very unimportant). The "performance" of each attribute and the "expectation" were rated with the same way such as the performance attributes. Respondents were asked to the 40 items in questionnaire survey and rate the degree to which they agreed for each item description, with value of 1 was representing the lowest degree item and value of 5 was representing the highest measurement for all aspects.

\subsection{Data Collection}

This study was focused on student attitudes toward service quality of the boarding school. Data were collected at Amanatul Ummah Boarding school, Pacet, Mojokerto, Indonesia, from October to November of 2015. We distributed 180 questionnaires at this school, and only 175 usable questionnaires were returned to calculate. The valid return rate was $100 \%$ of 175 respondents. The percentage of men was $52.57 \%$ and women were $47.43 \%$.

\subsection{Data Analysis}

The author used 3D IPEA model to compare the importance, performance and expectation of Amanatul Ummah boarding school in this case study. Although IPA is a traditional tool, it can help to evaluate and analyze organizational service, and to allocate resources to the right place, the right people and with good facilities. IPA enables management to identify the major weaknesses and strengths of organizational success factors. Therefore, this research used the 3D IPEA and GAP analysis model to evaluate the performance and importance of boarding school of Amanatul Ummah. A total of 175 respondents completed the research instrument for this study, and the result is described in section 4 under.

\section{Results and Analysis}

\subsection{IPEA Model}

This research differentiated the investigated into two groups of aspects and nine categories. First group is management aspects; (a) Educational system, such as method, learning environment, learning material, daily exercise and homework (5 items); (b) school expense; entry tuition fee, other dues (3 items); (c) school facilities, such as security system and food system (2 items); and, (d) teacher, such as intelligent, professionalism, skill, competence, attitude (5 items).

Second group is building facility aspects; (e) classroom, such as cleanness, neatness, quantity, natural air and natural lighting (5 items), (f) mosque, such as cleanness, neatness, speaker system, and lighting (4 items), (g) cafeteria (canteen), such as cleanness, neatness, food, drink and goods (5 items), (h) hostel, such as cleanness, neatness, quantity, natural air and bed (5 items), and (i) toilet, such as cleanness, neatness, quantity, water and lighting (5 items).

Based on the nine categories were performed in the study, forty questions were raised in a Likert scale of five scores. The complete list of 40 questions was shown in Table 1 below, which examined the response of all the attributes to assess the respondents' perception of the service of boarding school, and also the level of importance for each item. Table 1 shows the value of the difference between the importance, performance and expectations for the 40 attributes and GAP between all the attributes of the study. All score indicates the level of interest and expectations prove to differ significantly from the performance scores. The results further indicate that the rate of interest means that for all the items that are higher than the level of performance, it reflects that the existence of the quality gap. While respondents considered that each item be important in any overall evaluation based on their experience. As for the attribute of school facilities do not perform at a level that reflects the importance of the existing performance.

According to the result in Table 1, the expectation attributes are not contributed as well as view a grid in coordinate for any quadrant of IPEA model. The expectation values for all attribute are positive or more than 2.5, that means the position on the grid fall on quadrant 1 to 4 . The expectation attribute only show the GAP value between other attributes, the result is described in "GAP analysis" section.

Translating the findings result in terms of quadrants as shows in Figure 3, fifteen items fell under Quadrants 1-4. The $\mathrm{x}$-axis in the figure above represents the performance attributes, and the $\mathrm{y}$-axis represents the importance attributes. The cross-hairs (red lines) were located at the mean of scores. The mean values for performance (3.50) and importance (4.125) were used to split the axes of cross-hair placement; this is a relative judgment rather than an absolute measure, according to argue of Martilla et al. (1977). 
Table 2. The attribute and GAP values

\begin{tabular}{|c|c|c|c|c|c|c|c|c|}
\hline \multirow[b]{2}{*}{ No } & \multirow[b]{2}{*}{ Code } & \multirow[b]{2}{*}{ Attribute } & \multicolumn{3}{|c|}{ COORDINATE ATTRIBUTE } & \multirow{2}{*}{$\begin{array}{c}\text { GAP } \\
\text { IP }\end{array}$} & \multirow{2}{*}{$\begin{array}{c}\text { GAP } \\
\text { EP }\end{array}$} & \multirow{2}{*}{$\begin{array}{c}\text { GAP } \\
\text { IE }\end{array}$} \\
\hline & & & $X=\frac{\sum x}{K}$ & $Y=\frac{\sum y}{K}$ & $Z=\frac{\sum z}{K}$ & & & \\
\hline & A & Education system & & & & & & \\
\hline 1 & A.1 & Methode & 4.31 & 3.94 & 4.55 & $(0.37)$ & 0.62 & 0.25 \\
\hline 2 & A. 2 & Learning Environment & 4.60 & 3.99 & 4.45 & $(0.61)$ & 0.46 & $(0.15)$ \\
\hline 3 & A. 3 & Learning Material & 4.34 & 4.33 & 4.54 & (0.01) & 0.21 & 0.20 \\
\hline 4 & A. 4 & Daily Exercise & 4.69 & 4.37 & 4.49 & $(0.32)$ & 0.12 & $(0.20)$ \\
\hline \multirow[t]{2}{*}{5} & A.5 & Home Work & 4.37 & 4.18 & 4.39 & $(0.19)$ & 0.22 & 0.03 \\
\hline & B & School Expense & & & & & & \\
\hline 6 & B.1 & Entry Tution Fee & 2.99 & 3.78 & 4.54 & 0.79 & 0.76 & 1.55 \\
\hline \multirow[t]{2}{*}{7} & B. 2 & Monthly dues & 2.38 & 3.42 & 4.09 & 1.04 & 0.66 & 1.70 \\
\hline & C & School Facilites & & & & & & \\
\hline 8 & C. 1 & Security system & 2.46 & 4.47 & 4.62 & 2.02 & 0.14 & 2.16 \\
\hline 9 & C. 2 & Food system & 2.25 & 4.41 & 4.63 & 2.16 & 0.22 & 2.38 \\
\hline \multirow[t]{2}{*}{10} & C. 3 & Laundry system & 3.41 & 4.66 & 4.70 & 1.26 & 0.04 & 1.30 \\
\hline & $\mathrm{D}$ & Teacher & & & & & & \\
\hline 11 & D.1 & Intelligent & 3.17 & 4.60 & 4.69 & 1.43 & 0.09 & 1.52 \\
\hline 12 & D. 2 & Profesionalism & 2.98 & 4.67 & 4.70 & 1.69 & 0.03 & 1.73 \\
\hline 13 & D. 3 & Skill & 3.33 & 4.69 & 4.71 & 1.35 & 0.03 & 1.38 \\
\hline 14 & D.4 & Competence & 2.98 & 4.58 & 4.74 & 1.59 & 0.17 & 1.76 \\
\hline \multirow[t]{2}{*}{15} & D. 5 & Attitude & 3.93 & 4.80 & 4.83 & 0.87 & 0.03 & 0.90 \\
\hline & $E$ & Classroom & & & & & & \\
\hline 16 & E.1 & Cleanness & 3.36 & 4.63 & 4.66 & 1.27 & 0.03 & 1.30 \\
\hline 17 & E. 2 & Neatness & 2.97 & 4.73 & 4.76 & 1.76 & 0.03 & 1.79 \\
\hline 18 & E. 3 & Quantity & 3.14 & 4.58 & 4.65 & 1.44 & 0.07 & 1.51 \\
\hline 19 & E. 3 & Natural Lighting & 2.81 & 4.58 & 4.69 & 1.78 & 0.10 & 1.88 \\
\hline \multirow[t]{2}{*}{20} & E.4 & Natural Air & 3.69 & 4.55 & 4.70 & 0.86 & 0.15 & 1.01 \\
\hline & $\mathbf{F}$ & Cafetaria & & & & & & \\
\hline 21 & F.1 & Cleanness & 2.37 & 4.44 & 4.54 & 2.07 & 0.10 & 2.17 \\
\hline 22 & F.2 & Neatness & 2.57 & 4.66 & 4.86 & 2.09 & 0.20 & 2.29 \\
\hline 23 & F.3 & Food & 2.80 & 4.34 & 4.54 & 1.54 & 0.20 & 1.74 \\
\hline 24 & F. 4 & Drink & 2.65 & 4.49 & 4.64 & 1.84 & 0.15 & 1.99 \\
\hline 25 & F.5 & Goods & 3.56 & 4.53 & 4.71 & 0.97 & 0.18 & 1.15 \\
\hline \multirow[t]{2}{*}{26} & F. 6 & Price & 2.18 & 3.98 & 4.37 & 1.80 & 0.39 & 2.19 \\
\hline & G & Mosque & & & & & & \\
\hline 27 & G.1 & Cleanness & 2.67 & 4.88 & 4.91 & 2.21 & 0.03 & 2.24 \\
\hline 28 & G. 2 & Neatness & 2.36 & 4.82 & 4.89 & 2.46 & 0.06 & 2.53 \\
\hline 29 & G.3 & Speaker system & 3.91 & 4.56 & 4.69 & 0.65 & 0.13 & 0.78 \\
\hline \multirow[t]{2}{*}{30} & G.4 & Lighting & 4.11 & 4.54 & 4.70 & 0.42 & 0.17 & 0.59 \\
\hline & H & Hostel & & & & & & \\
\hline 31 & H.1 & Cleanness & 2.31 & 4.90 & 4.91 & 2.58 & 0.02 & 2.60 \\
\hline 32 & H. 2 & Neatness & 2.23 & 4.62 & 4.71 & 2.39 & 0.10 & 2.49 \\
\hline 33 & H.3 & Quantity & 3.19 & 4.90 & 4.74 & 1.70 & (0.15) & 1.55 \\
\hline 34 & H.4 & Natural air & 3.29 & 4.53 & 4.63 & 1.24 & 0.10 & 1.34 \\
\hline \multirow[t]{2}{*}{35} & H.5 & Bed & 2.13 & 4.47 & 4.63 & 2.35 & 0.15 & 2.50 \\
\hline & 1 & Toilet & & & & & & \\
\hline 36 & 1.1 & Cleanness & 2.26 & 4.69 & 4.76 & 2.43 & 0.07 & 2.50 \\
\hline 37 & 1.2 & Neatness & 2.43 & 4.83 & 4.88 & 2.40 & 0.05 & 2.45 \\
\hline 38 & 1.3 & Quantity & 2.40 & 4.91 & 4.94 & 2.51 & 0.03 & 2.54 \\
\hline 39 & 1.4 & Lighting & 3.85 & 4.55 & 4.63 & 0.71 & 0.07 & 0.78 \\
\hline 40 & 1.5 & Water & 2.60 & 4.75 & 4.77 & 2.15 & 0.02 & 2.17 \\
\hline
\end{tabular}

The following points describe each IPA quadrant based on results in Figure 3;

1) The "Keep up the good work" quadrant. Five items that fall into this quadrant are the education system attribute and teacher attitude. This quadrant, comprising five items, suggests areas where the school is doing well and must continue the good work.

2) The "Concentrate here" quadrant. Items that fall into this quadrant represent key areas that must improve as a top priority. Seven items are located in this zone. Include two items of school facilities (security system and food 
system) belong to the school facility variables which need immediate action from the school.

3) The "Low priority" quadrant. Any item that falls into this quadrant is non-important and does not pose a boarding school threat. It is unnecessary for school management to focus additional any effort here. Two items (tuition fees and monthly dues) are located in this zone. This quadrant means that although the performance of attribute was bad value. The other side the importance of this attribute is low according to the student perception.

4) The "Possible overkill" quadrant is a strange and confused area according to the student perception. This quadrant shows the result of the importance attribute lower than the performance attribute. The finding of this condition means that the school management did the best effort in these items. This quadrant reflects a lower and misuse of school resources too. Two items (method and learning environment) belong to this quadrant. The management aspects that located in this zone are a low-priority to improve.

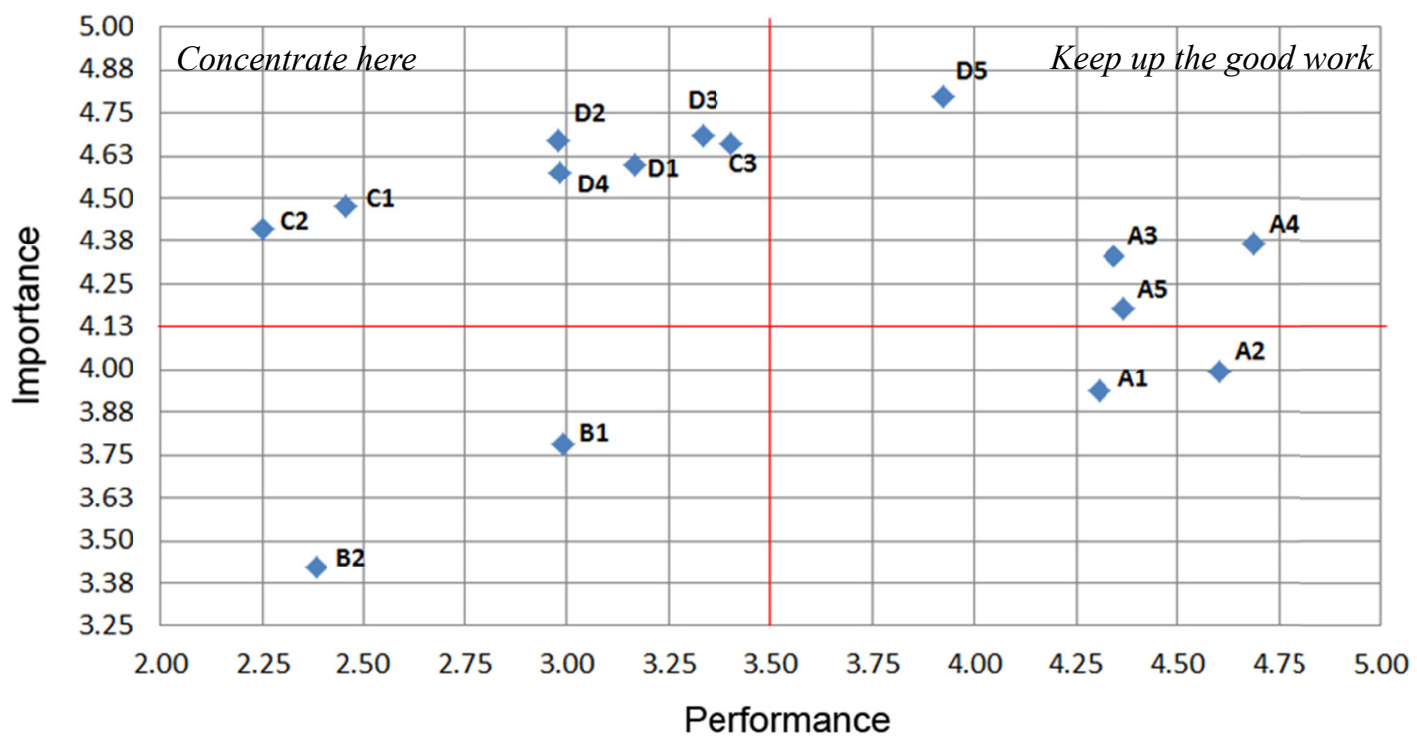

Low priority

Possible overkill

Figure 3. The quadrant of Importance-Performance Analysis for management aspect

The following explanations describe each IPA quadrant follow the results in Figure 4;

1) The "Keep up the good work" quadrant. Items that fall into this quadrant are the condition of building facilities such as cleanness of classroom, quantity of classroom, natural air of building, goods in cafeteria, speaker system and lighting in the mosque, quantity of hostel, and lighting in the toilet. This quadrant suggests areas where the boarding school is doing well and has to continue the work in this attributes.

2) The "Concentrate here" quadrant. All items which fall into this quadrant represent that boarding school must improve as a priority. Fourteen items are located in this zone, such as neatness of the building, natural lighting of the building, quantity of hostel room and condition of the toilet. This means the building facility variables in this quadrant should immediate action from the school to improve the quality of building service.

3) The "Low priority" quadrant. Any item that falls into this quadrant is non-important attribute. Consequently, it is unnecessary for school management to focus additional effort. Only two items are located in this zone, about price and number of food in cafeteria.

4) The "Possible overkill" quadrant that located in this zone is a low-priority region. There is no any items fell in this quadrant, which means unnecessary for management to improve any effort here. 


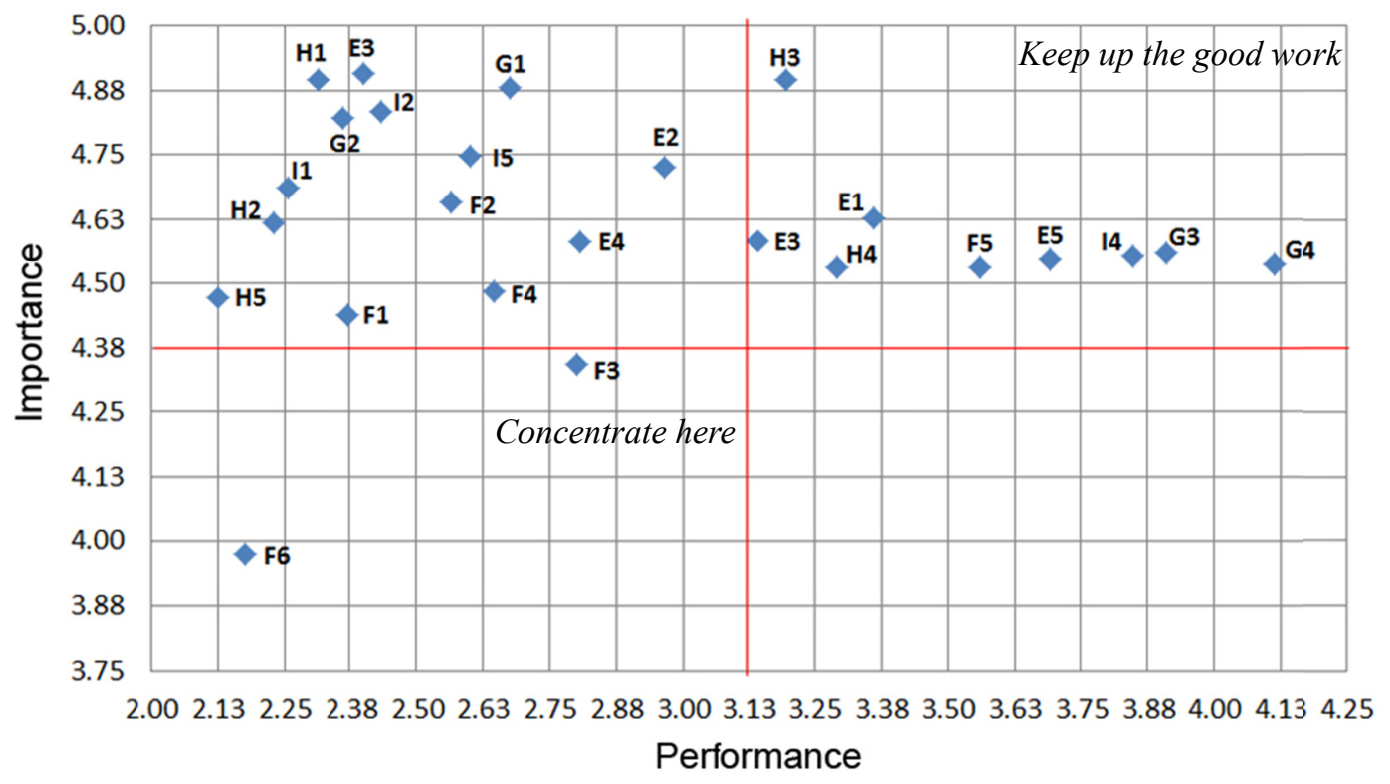

Low priority

Possible overkill

Figure 4. The quadrant of Importance-Performance Analysis for service quality aspect

\subsection{GAP Analysis}

By applying the GAP analysis to all items, it is possible to find out which short-falls of attributes are in the boarding school. It is possible to target improving on those necessary attributes that require the most attention from the school management. The GAP analysis results in the optimal use of resources in terms of improving the overall performance of the boarding school.

For the boarding school, the GAP analysis can be used to identify which attribute have most importance aspects, from value of the importance and expectation compared with value of the performance. Figure 4 is shown GAP of three attributes which compare all of the attributes.

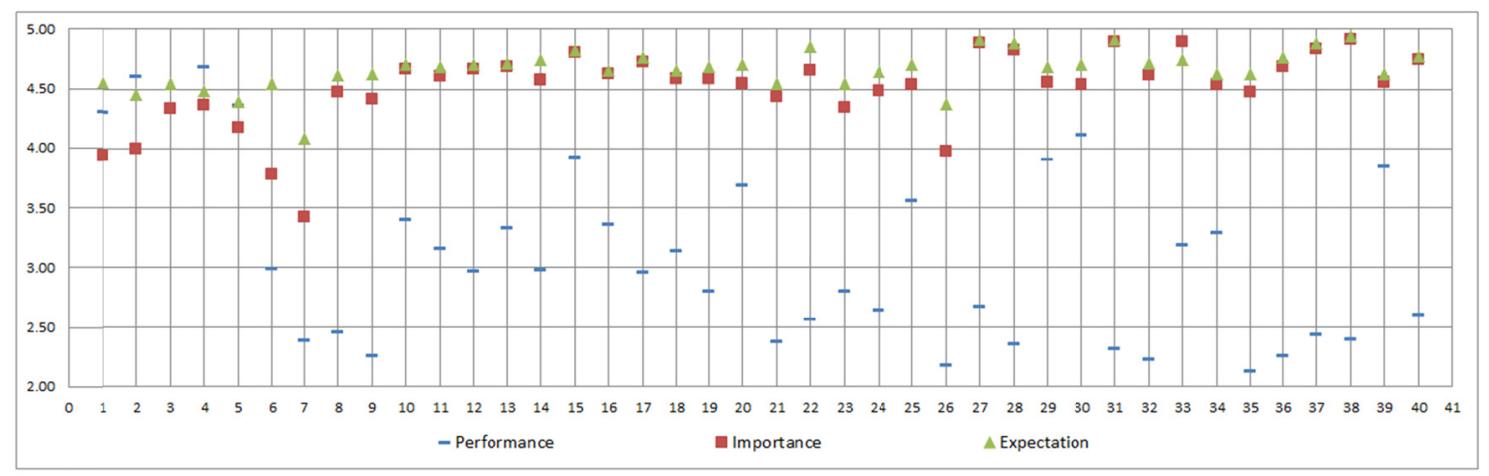

Figure 5. GAP of three attributes (performance - importance - expectation)

According to Table 1 and Figure 5, GAP between the attribute is shown that high value of expectation from the student perception almost in all items. GAP of the expectation and the importance value from the building and service quality was dominant. From the attribute number 6 to number 40, expectation of the student to this item were very wide. This finding means the school management should improve the service quality of these items.

\subsection{D IPEA Model}

Refer to Table 1 and calculation of the attributes in Table 3, this study is finding the unique results which 
different with traditional IPA. In this study, the value of the 'expectation' attribute is higher, compared with those in the other attributes. This result affected the dominance of the calculated value and the quadrant placement. The following table is table of attribute calculation and quadrant placement in 3D IPEA model.

Table 3. Calculation of attribute and quadrant placement

\begin{tabular}{|c|c|c|c|c|c|c|c|c|c|}
\hline \multirow[t]{2}{*}{ No } & \multirow[t]{2}{*}{ Code } & \multirow[t]{2}{*}{ Atribut } & $X=\frac{\sum x}{K}$ & $Y=\frac{\sum y}{K}$ & $Z=\frac{\sum z}{K}$ & \multirow[t]{2}{*}{ CPE } & \multirow[t]{2}{*}{ CIE } & \multirow[t]{2}{*}{ CPI } & \multirow[t]{2}{*}{$\mathbf{Q}$} \\
\hline & & & $\mathbf{P}$ & I & $\mathbf{E}$ & & & & \\
\hline & A & Education system & & & & & & & \\
\hline 1 & A.1 & Methode & 4.31 & 3.94 & 4.55 & -0.246 & -0.617 & 0.371 & VII \\
\hline 2 & A. 2 & Learning Environment & 4.60 & 3.99 & 4.45 & 0.149 & -0.457 & 0.606 & III \\
\hline 3 & A.3 & Learning Material & 4.34 & 4.33 & 4.54 & -0.200 & -0.211 & 0.011 & VII \\
\hline 4 & A.4 & Daily Exercise & 4.69 & 4.37 & 4.49 & 0.200 & -0.120 & 0.320 & III \\
\hline \multirow[t]{2}{*}{5} & A.5 & Home Work & 4.37 & 4.18 & 4.39 & -0.029 & -0.217 & 0.189 & VII \\
\hline & B & School Expense & & & & & & & \\
\hline 6 & B.1 & Entry Tution Fee & 2.99 & 3.78 & 4.54 & -1.554 & -0.760 & -0.794 & VIII \\
\hline \multirow[t]{2}{*}{7} & B. 2 & Monthly dues & 2.38 & 3.42 & 4.09 & -1.703 & -0.663 & -1.040 & VIII \\
\hline & C & School Facilites & & & & & & & \\
\hline 8 & C.1 & Security system & 2.46 & 4.47 & 4.62 & -2.160 & -0.143 & -2.017 & VIII \\
\hline 9 & C. 2 & Food system & 2.25 & 4.41 & 4.63 & -2.377 & -0.217 & -2.160 & VIII \\
\hline \multirow[t]{2}{*}{10} & C. 3 & Laundry system & 3.41 & 4.66 & 4.70 & -1.297 & -0.040 & -1.257 & VIII \\
\hline & D & Teacher & & & & & & & \\
\hline 11 & D.1 & Intelligent & 3.17 & 4.60 & 4.69 & -1.520 & -0.086 & -1.434 & VIII \\
\hline 12 & D. 2 & Profesionalism & 2.98 & 4.67 & 4.70 & -1.726 & -0.034 & -1.691 & VIII \\
\hline 13 & D. 3 & Skill & 3.33 & 4.69 & 4.71 & -1.383 & -0.029 & -1.354 & VIII \\
\hline 14 & D. 4 & Competence & 2.98 & 4.58 & 4.74 & -1.760 & -0.166 & -1.594 & VIII \\
\hline \multirow[t]{2}{*}{15} & D. 5 & Attitude & 3.93 & 4.80 & 4.83 & -0.903 & -0.029 & -0.874 & VIII \\
\hline & $E$ & Classroom & & & & & & & \\
\hline 16 & E.1 & Cleanness & 3.36 & 4.63 & 4.66 & -1.297 & -0.029 & -1.269 & VIII \\
\hline 17 & E. 2 & Neatness & 2.97 & 4.73 & 4.76 & -1.794 & -0.034 & -1.760 & VIII \\
\hline 18 & E. 3 & Quantity & 3.14 & 4.58 & 4.65 & -1.509 & -0.069 & -1.440 & VIII \\
\hline 19 & E. 4 & Natural Lighting & 2.81 & 4.58 & 4.69 & -1.880 & -0.103 & -1.777 & VIII \\
\hline \multirow[t]{2}{*}{20} & E.5 & Natural Air & 3.69 & 4.55 & 4.70 & -1.011 & -0.154 & -0.857 & VIII \\
\hline & $\mathbf{F}$ & Cafetaria & & & & & & & \\
\hline 21 & F.1 & Cleanness & 2.37 & 4.44 & 4.54 & -2.171 & -0.103 & -2.069 & VIII \\
\hline 22 & F. 2 & Neatness & 2.57 & 4.66 & 4.86 & -2.291 & -0.200 & -2.091 & VIII \\
\hline 23 & F. 3 & Food & 2.80 & 4.34 & 4.54 & -1.743 & -0.200 & -1.543 & VIII \\
\hline 24 & F.4 & Drink & 2.65 & 4.49 & 4.64 & -1.994 & -0.154 & -1.840 & VIII \\
\hline 25 & F.5 & Goods & 3.56 & 4.53 & 4.71 & -1.149 & -0.177 & -0.971 & VIII \\
\hline \multirow[t]{2}{*}{26} & F. 6 & Price & 2.18 & 3.98 & 4.37 & -2.194 & -0.394 & -1.800 & VIII \\
\hline & G & Mosque & & & & & & & \\
\hline 27 & G.1 & Cleanness & 2.67 & 4.88 & 4.91 & -2.240 & -0.034 & -2.206 & VIII \\
\hline 28 & G.2 & Neatness & 2.36 & 4.82 & 4.89 & -2.526 & -0.063 & -2.463 & VIII \\
\hline 29 & G.3 & Speaker system & 3.91 & 4.56 & 4.69 & -0.777 & -0.126 & -0.651 & VIII \\
\hline \multirow[t]{2}{*}{30} & G.4 & Lighting & 4.11 & 4.54 & 4.70 & -0.589 & -0.166 & -0.423 & VIII \\
\hline & H & Hostel & & & & & & & \\
\hline 31 & H.1 & Cleanness & 2.31 & 4.90 & 4.91 & -2.600 & -0.017 & -2.583 & VIII \\
\hline 32 & H. 2 & Neatness & 2.23 & 4.62 & 4.71 & -2.486 & -0.097 & -2.389 & VIII \\
\hline 33 & H.3 & Quantity & 3.19 & 4.90 & 4.74 & -1.549 & 0.154 & -1.703 & VI \\
\hline 34 & H. 4 & Natural air & 3.29 & 4.53 & 4.63 & -1.337 & -0.097 & -1.240 & VIII \\
\hline \multirow[t]{2}{*}{35} & H. 5 & Bed & 2.13 & 4.47 & 4.63 & -2.503 & -0.154 & -2.349 & VIII \\
\hline & 1 & Toilet & & & & & & & \\
\hline 36 & I.1 & Cleanness & 2.26 & 4.69 & 4.76 & -2.503 & -0.074 & -2.429 & VIII \\
\hline 37 & 1.2 & Neatness & 2.43 & 4.83 & 4.88 & -2.446 & -0.046 & -2.400 & VIII \\
\hline 38 & 1.3 & Quantity & 2.40 & 4.91 & 4.94 & -2.543 & -0.034 & -2.509 & VIII \\
\hline 39 & 1.4 & Lighting & 3.85 & 4.55 & 4.63 & -0.783 & -0.074 & -0.709 & VIII \\
\hline 40 & 1.5 & Water & 2.60 & 4.75 & 4.77 & -2.171 & -0.023 & -2.149 & VIII \\
\hline
\end{tabular}

According to Table 3, placement of 3D IPEA quadrant is shown that quadrants VIII is dominated. Higher value of the expectation attribute from the building service quality aspect and management aspect are affected these 
results. The findings of different quadrant are attribute of education system; A2. Learning Environment (Quadrant 3), and A4. Daily Exercises (Quadrant 3), and in attribute of building service quality; H3. Quantity of hostel (Quadrant 6). Placement of quadrant 3 cause of the value performance of this attributes is higher than the value of expectation and importance attributes. These results mean the students fells very satisfaction with this attributes. And placement of quadrant 6 shows that the value of importance attribute higher than the value expectation attribute. This condition is very rare case; all of respondent put the value of 'expectation' higher than 'importance' in this study, except this attribute (quantity of hostel). These results shown the respondent thought that quantity of hostel is has exceeded their demand.

\section{Conclusions}

The purpose of this research was to identify gaps of current service by applying both of the IPEA model and GAP analysis technique. A 3D IPEA model was proposed by adding in the expectation attribute of student perception in order to find out the problems causing the gaps between attribute.

According to the result in table of GAP analysis, the expectation attributes are not contributed as well as view a grid in coordinate for any quadrant of IPEA model. The expectation values for all attribute are positive or more than 2.5, that means the position on the grid fell into quadrant 1 to 4 . The expectation attribute only shows the GAP value between other attributes. Although, this research results is only shows the value of importance and performance attribute to create a grid view and quadrant position.

The importance-performance results indicate that management aspects in boarding school are running well, which fall into quadrant 1 (Keep up the good work). And the other side, the quadrant 2 (Concentrate here) should direct attention from school management, and making improvement in this quadrant. Seven items of management aspect fell into this quadrant and fourteen items of building quality fell into this quadrant. These findings suggest that a management and building facility aspects are necessary to better match with the school and student character and enhance the service quality.

This research results provide further evidence of the importance of the education system, and management can use these IPEA results to create a development strategy and upgrading the building quality aspect based on the performance and importance that shown in four quadrants. IPEA in this study was an effective method to measure perspective of end user in good facility, teacher performs, building facilities, and others attribute. The finding suggests that management of school is necessary to improve and should in better condition than existing condition, such as facilities of classroom, toilet, hostel, cafeteria, cleanness of the mosque, and others.

In this study, IPEA model can be used to identify the service quality gaps and the problems causing the gaps between attribute can be analyzed. But the expectation attribute not contributed in the analysis, surely that this attribute can be eliminated. The similarity value between the importance and the expectation attributes are the main cause. For future research, it is suggested to differentiate the similar attribute to different aspect which can be putted on $\mathrm{z}$ axis to create the 3D view of grid analysis. It would be better if the $3 \mathrm{D}$ model is a combination of IPA method and internal management, so that the $\mathrm{z}$ axis is a factor that inherent in the system of service organizations such as boarding schools, and others.

\section{Acknowledgments}

This work has been supported by Department of Tarbiyah, Institute Pesantren KH Abdul Chalim, Mojokerto, Indonesia. The authors would like to thank the students, who answered the questionnaires and other teachers for allowing time in their classes for carrying out the survey. We would also like to thank Amanatul Ummah Boarding School's principal for authorizing the use of the questionnaires in this study.

\section{References}

Abalo, J., Varela, J., \& Manzano, V. (2007). Importance values for Importance-Performance Analysis: A formula for spreading out values derived from preference rankings. Journal of Business Research, 60(2), 115-121.

Chen, Y.-C., \& Lin, S. (2013). Applying Importance-Performance Analysis for Improving Internal Marketing of Hospital Management in Taiwan International. Business Research, 6(4), 46-54.

Ennew, C. T., Reed, G. V., \& Binks, M. R. (1993). Importance-performance analysis and the measurement of service quality. European Journal of Marketing, 27, 59-70. http://dx.doi.org/10.1108/03090569310026402

Kitcharoen, K. (2004). The importance-performance analysis of service quality in administrative departments of private universities in Thailand. ABAC Journal, 24(3), 20-46.

Lin, S.-P., Chan, Y.-H., \& Tsai, M.-C. (2009). A Transformation Function Corresponding to IPA and Gap Analysis. TQM \& Business excellence, 20(8), 829-846. 
Lin, S.-P., Chan, Y.-H., \& Tsai, M.-C. (2009). A transformation function corresponding to IPA and gap analysis. Total Quality Management \& Business Excellence, 20(7), 829-846.

Linda, S. L., \& To, W. M. (2010). Importance-performance analysis for public management decision making: An empirical study of China's special administrative region. Management Decision, 48(2), 277-295. http://dx.doi.org/10.1108/00251741011022626

Martilla, J. A., \& James, J. C. (1977). Importance-performance analysis. Journal of Marketing, 41, 77-78. http://dx.doi.org/10.2307/1250495

Matzler, K., Sauerwein, E., \& Heischmidt, K. (2003). Importance-performance analysis Revisited: the role of the factor structure of customer satisfaction. The Service Industries Journal, 23(2), 112-129.

O’Neill, M. A., \& Palmer, A. (2004). Importance-performance analysis: A useful tool for directing continuous quality improvement in higher education. Quality Assurance in Education, 12(1), 39-52. http://dx.doi.org/10.1108/09684880410517423

Silva, F., \& Fernandes, O. (2010). Using Importance-Performance Analysis in Evaluating of Higher Education: A Case Study. ICEMT 2010 International Conference on Education and Management Technology. IEEE.

Silva, F., \& Fernandes, O. (2011). Importance-Performance Analysis as a Tool in Evaluating Higher Education Service Quality: The Empirical Results of Estig (IPB), Creating Global Competitive Economies: A 360-Degree Approach, 306-315

Tahir, I. M., Bakar, N. M. A., \& Ismail, W. Z. W. (2008). Customer Expectations and Perceptions of Service Quality in Islamic Banking: Evidence from Malaysia. Journal of Islamic Economics, Banking and Finance (JIEBF), 4(3), 69-82.

Wong, M. S., Hideki, N., \& George, P. (2011). The use of importance-performance analysis (IPA) in evaluating Japan's e-government services. Journal of Theoretical and Applied Electronic Commerce Research, 6(2), 17-30.

Wu, H. H., \& Shieh, J. I. (2010). Quantifying uncertainty in applying importance-performance analysis. Quality and Quantity, 44, 997-1003. http://dx.doi.org/10.1007/s11135-009-9245-8

\section{Copyrights}

Copyright for this article is retained by the author(s), with first publication rights granted to the journal.

This is an open-access article distributed under the terms and conditions of the Creative Commons Attribution license (http://creativecommons.org/licenses/by/3.0/). 